beautiful specimens of Crinoids and Cystidea have been collected."

Now deep-water forms are, at the present day, usually more ancestral than contemporary shallow-water forms, and the same rule seems to have held good in past ages; we may therefore reasonably suppose that, while $B$. pinnulatus was living in shallow water at Dudley, other more ancestral forms were living in deeper seas, and that, as the Dudley sea-bottom sank, these latter forms came in. Even if this be not allowed, it must be remembered that the rarity of well-preserved Crinoids in all beds below the Upper Wenlock Limestone renders any objections based on negative evidence of very small moment.

XLII.-On the Occurrence of Halistemma in British Waters. By the Rev. A. D. Sloan, M.A., B.Sc. (Edinb.), St. Andrews.

\title{
[Plate XII.]
}

The first Siphonophore recorded in St. Andrews Bay was obtained in the bottom tow-net some distance off the Castle on the 16th of May. When brought into the Marine Laboratory it was in a moribund condition, and was preserved in alcohol before it was given me for examination. Unfortunately the bracts had all fallen off and the tentacles were very much contracted.

The specimen evidently belongs to the genus Agalmopsis of Sars, under which, however, that observer appears to describe several genera; but, if we are to follow the new arrangement of Hæckel in his recent reconstruction of the Siphonophora, we must put it in the genus Halistemma, in which he includes the Halistemma of Huxley, the Agalmopsis punctata of Kölliker, and those forms of the Agalmopsis of Sars whose tentacle-branches end in simple terminal filaments.

The creature or colony of creatures, according as its various parts are regarded as organs or individuals, consists of a long flexible stem, along which the various structures (organs or individuals) are distributed in an irregular manner without definite nodes and internodes. The stem presents a division into an anterior shorter and a posterior longer portion, called respectively the nectosome and the siphosome. The nectosome is the locomotory part of the creature and is that portion of the trunk which bears the swimming-bells, and after being 
carried forward in the form of a slender axis terminates in the float or pneumatophore. The siphosome constitutes the greater part of the creature and consists of an elongated flexible axis bearing at intervals the bracts, polypes with tentacles, mouthless polypes without tentacles, and various urn-like structures and clusters, which appear to represent the excretory and reproductive organs. The nectosome or portion of the axis which bears the swimming-apparatus terminates in a large oval float or pneumatophore, whose anterior wall contains a great deal of reddish pigment. In the Agalmidæ the float is described as being very small in comparison with the swimming-bells; but in this form it is proportionally large, being about three times larger than the largest swimming-bell. 'The comparatively large size of the float cannot altogether be attributed to contraction of the other parts during preservation, as it is noticeable in a reugh sketch made by Mr. Holt when the creature was still alive.

Behind the float the nectosome presents the appearance of a narrow delicate cylinder, devoid of lateral structures, and extending about two and a half times the length of the long. axis of the pneumatophore. It is quite straight throughout all its length, and in it Mr. Holt figures several little bubbles or globules, which are, however, not seen in the preserved specimen. The length of this stalk is comparatively great; but it is very contractile, and may have been fixed in its extended state.

This narrow stalk passes somewhat suddenly into a thicker portion of the axis, along which the swimming-bells (nectocalyces, nectophores) are distributed, and which exhibits a spiral twist. At the place where the narrower joins the thicker portion of the nectosome is a small cluster of buds, which represent young swimming-bells. In the specimen may be seen three or four very small buds and then two rows of four buds each, which are continuous with two rows of functional swimming-bells. The buds increase in size as we proceed distally along the axis, and so do the fully developed nectocalyces, the distal ones being the largest.

The functional swimming-bells consist of a large bellshaped portion variously compressed and a short pedicle by which they are connected to the axis. They are six in number, arranged in two rows of three. Behind the nectocalyces is a portion of the nectosome devoid of structures, but presenting several little knobs, which may represent the stalks of nectocalyces whose bells have fallen off.

'The nectosome passes into the siphosome or polyp-bearing part of the axis, along which the protective, nutritive, excre- 
tory, and reproductive structures are distributed. It is long, very extensible and contractile, and flexible. In the specimen under consideration it ends abruptly, as if a portion of it were wanting. The structures which it bears are crowded together at the proximal end, but occur more sparsely as we proceed distally.

The anterior part of the siphosome is covered with buds, which are evidently young polypes or feeding individuals, and then follow more fully matured polypes as we pass along the axis. Of these polypes or feeding individuals there are two incipient and nine fully developed, the former following pretty closely on one another and the others at increased intervals. The first distinct polyp exhibits a large basal portion and a small oral portion, and at the base may be seen the contracted tentacle. The full-grown polypes, in their preserved condition, are all acorn-shaped, presenting a large basal part, corresponding to the cup of the acorn, and then a cone-shaped portion, somewhat elongated and terminating in a shallow cone, in which the mouth is situated. Round the basal portion the many-branched tentacle may be seen in a highly contracted state. The ninth or last polyp is represented only by its basal portion and coiled tentacle, the larger part of it having been torn off.

The tentacles unfortunately were all in a contracted condition, and this is to be regretted, as Hæckel, following Eschscholtz and Huxley, in his new arrangement of the Siphonophora, employs the characteristic appearance of the terminations of the branches of the tentacles for the distinction of genera. As far as I could make out, however, the tentacles of the specimen exhibit the simplest form of termination, and would therefore point to its belonging to the genus Halistemma.

Along the internodes or portions of the axis between the polypes numerous other structures are distributed. Soine of them resemble closed polypes, some little urns, and others bunches of grapes, and these seemingly represent sensory, excretory, and reproductive organs.

The closed polypes, called palpons by Hæckel, are regarded by him to be sensory in function. The urns in which there is a mouth or opening he considers to be excretory. 'The cluster-like structures again are gonodendra, of which several occur in each internode.

Bracts are figured by Mr. Holt in his drawing, although very sparingly. In the preserved specimen I have not been able to alight on one. T'iney are leat-like structures, triangular in form. 
The specimen evidently belongs to the genus Halistemma, but differs from all the forms of Halistemma and Agalmopsis I have seen figured in the proportionally larger size of the pneumatophore and the relatively greater length of the portion of the nectosome between the pneumatophore and the nectocalyces. The length of the specimen in its preserved condition is $1 \frac{11}{16}$ inch.

Another specimen evidently belonging to the same species was obtained a few days later. It measured about $\frac{1}{2}$ inch in length and was in a very dilapidated condition. Indeed it consisted only of the nectosome with its pneumatophore, but stripped of the nectocalyces and a portion of the siphosome, from which all the structures had been removed. It, however, showed the same relatively large size of pneumatophore which characterized the other specimen.

\section{Note by Prof. M'Intosh.}

The occurrence of Halistemma on the east coast of Britain is of great interest; indeed, the Siphonophores are there, as a rule, conspicuous by their absence. Of the other Siphonophores Dipliyes has very rarely been seen in good condition in the inshore waters of Britain, perhaps the most striking instance being in Lochmaddy, North Uist, in 1865, where it occurred in great beauty amongst the hordes of Salpa, swimming actively through the water and avoiding the bottles that were used in its capture. Amongst the Physophora again Physalia is seen occasionally on the west coast of England and the Outer Hebrides, very fine examples having been procured off Southport in 1874. Velella is common on the western shores of North Uist, and also is found in considerable numbers at various parts of the west coast of England from the extreme south northward to Scottish waters. The small size of the specimens described by Mr. Sloan would alone have rendered them apt to be overlooked amidst the varied contents of the tow-nets.

\section{EXPLANATION OF PLATE XII.}

The accompanying figure is the reduction of a drawing marle from the preserved specimen with the aid of Abbe's camera lucida. The objective used was Zeiss's $a_{3}$ and the eyepiece Zeiss's no. 2.

a. Pneumatophore.

b. Young nectocalyces.

c. Functional nectocalyces.

d. Incipient siphons or feeding polyps, with coiled tentacle at hase.

e. Mature feeding polyps.

$f$. Contracted branches of coiled tentacle.

g. Palpons or sensory polypes and cystons or excretory polypes.

h. Gonodendra. 


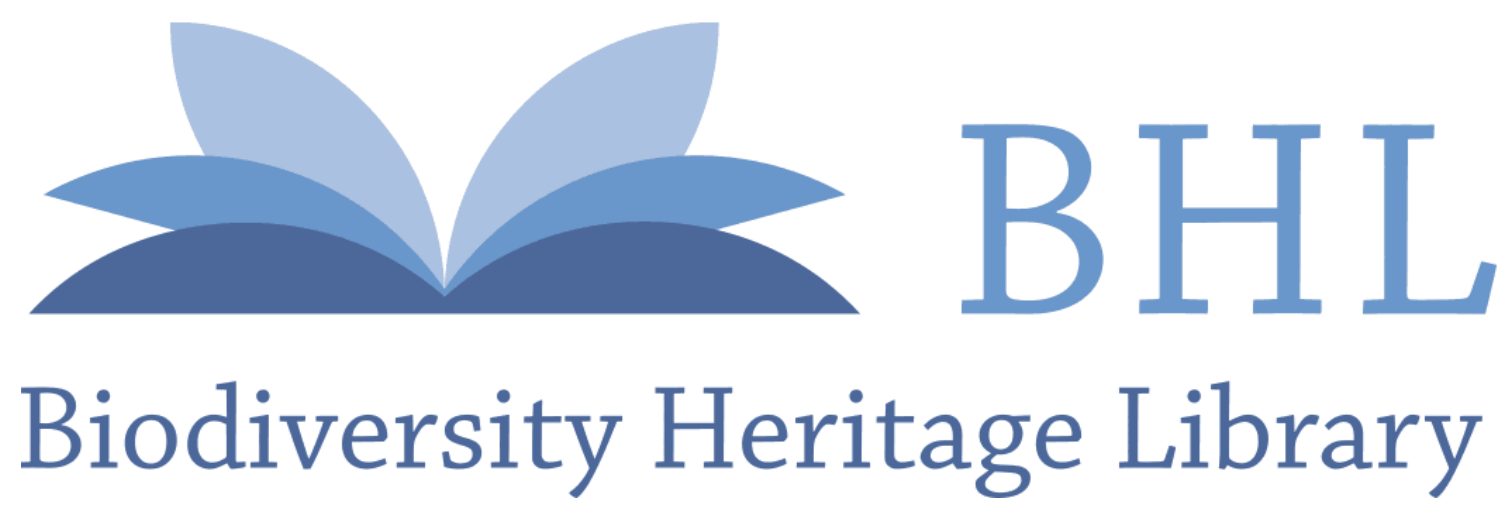

Sloan, A D. 1891. "XLII.-On the occurrence of Halistemma in British Waters." The Annals and magazine of natural history; zoology, botany, and geology 7 , 413-416. https://doi.org/10.1080/00222939109460634.

View This Item Online: https://www.biodiversitylibrary.org/item/63422

DOI: https://doi.org/10.1080/00222939109460634

Permalink: https://www.biodiversitylibrary.org/partpdf/59207

\section{Holding Institution}

University of Toronto - Gerstein Science Information Centre

\section{Sponsored by}

University of Toronto

\section{Copyright \& Reuse}

Copyright Status: NOT_IN_COPYRIGHT

This document was created from content at the Biodiversity Heritage Library, the world's largest open access digital library for biodiversity literature and archives. Visit BHL at https://www.biodiversitylibrary.org. 